\title{
A Study of English Verbal Ability of School Students of Gujarat State with Respect To Gender, Age and Area
}

\author{
Dr Sanjay Gupta ${ }^{1}$, Sudhir Kumar Yadav²*
}

\section{ABSTRACT}

Aptitude tests have existed from the decade of 1940s with the title of the General Aptitude Test Battery. This was an initiative of the United States Employment Service which for the following decades, have helped students to determine their career aptitude. It has been documented that it leads people to their respective choice of careers with an up sloping growth and with so much feelings of professional fulfillment. Presently, the career aptitude tests have evolved to include not only the tests of skills and abilities but also the tests of personality class or type. Aptitude is not synonymous to one's intelligence or mental abilities. It should not be confused with other terms such as intelligence quotient or intelligence level that dictate mental classifications such as the genius, child prodigy, mentally delayed, and mentally retarded, to name a few. Aptitude simply means and implies an individual's good fit and suitability for a certain skill or task in a given environment.

Now that it has been settled that career aptitude tests can be administered to both high school undergraduates and graduates, there emerged several discussions regarding the benefits taking the career aptitude tests may render to students who are in their junior and senior high school years, versus when it is taken at a latter age. Early adolescence and late adolescence stage is filled with a lot of developmental tasks and adjustments. Chances of peer pressure, influences of advertisements as well as of those who are within their social circle may create more confusion to the many decisions they have to make, including career related decisions. Although this conclusive theory does not apply to all, this implies that increasing their awareness will somehow provide them an idea of a path that they may take, or a direction in their future careers, and decrease the chances of career mismatches by strengthening their viewpoint on their capabilities and matched career options.

\footnotetext{
${ }^{1}$ Lecturer in Selection Grade, Department of Education, Kadi University, Gandhinagar, India

${ }^{2}$ Ph.D scholar, Department of Education, Kadi University, Gandhinagar, India

*Responding Author
}

Received: December 25, 2016; Revision Received: January 14, 2017; Accepted: January 27, 2017

(C) 2017 Gupta S, Yadav S; licensee IJIP. This is an Open Access Research distributed under the terms of the Creative Commons Attribution License (creativecommons.org/licenses/by/2.0), which permits unrestricted use, distribution, and reproduction in any Medium, provided the original work is properly cited. 


\section{A Study of English Verbal Ability of School Students of Gujarat State with Respect To Gender, Age and Area}

A self constructed test by researcher was used to test the English Verbal Ability of the school students of Gujarat state from the age of 11 years to 13 years. The data collected so were analyzed using 'critical ratio' to test the significance of difference of area and sex on the students.

Keywords: English Verbal Ability, School, Students, Gujarat State, Gender, Age, Area

The current generation is witnessing an unprecedented explosion of knowledge. Today, we live in a world where because of change in knowledge, shifting demographics, technological changes and economical globalization, jobs and needs are created and dissolved simultaneously. Due to explosion of knowledge for certain professionals their present knowledge and skills may become out of date in a very quick time. Thus, education alone is not enough for people to prepare them self to make a stand in this ever fast evolving world.

Today's parents do realize that they have to prepare their child for a kind of world, where change is product of every moment. Everyone needs to be able to compete and survive in the $21^{\text {st }}$ century's work environment. Awareness of this 'need for survival' is named as carrier literacy. For any job, it is required to get a special qualification which is mandatory for the job. To get this qualification students go to education institutes. Due to population explosion today there are more candidates for any job than the vacancies ever. So there becomes very fierce competition in every field, which leads to undue stress for children and his parents. So it becomes necessary to know oneself strong and weak points which will help in the carrier progression.

The definition of aptitude, according to the Merriam-Webster online dictionary, is "an inclination... tendency... natural ability... general suitability”. Here this suitability can be worked out by employing the career aptitude test on a desired group of people to find out the desired people out of a given group.

So, now it is more important to know about 'self'. This awareness helps student to identify their talent. But this is not a simple process for talented students. There are many ways to know about 'self' like; ability tests, achievement tests, various competitions, continuous assessment, interpretation etc. physiological parameters. These tests can be conducted at the higher secondary level in school because this is a stage where a student has to make a choice about their career. Therefore researcher decided to conduct a study in the field of the English Verbal Ability because English language is a much sought after subject these days.

\section{Objectives}

(1) To construct and standardized the English Verbal Ability test for school students.

(2) To study the comparative effect of area on English Verbal Ability of school students.

(3) To study the comparative effect of gender on English Verbal Ability of school students.

(C) The International Journal of Indian Psychology, ISSN 2348-5396 (e)| ISSN: 2349-3429 (p) | 130 


\section{A Study of English Verbal Ability of School Students of Gujarat State with Respect To Gender, Age and Area}

(4) To study the comparative effect of age on English Verbal Ability of school students.

(5) To establish norms on English Verbal ability test for school students.

\section{Hypotheses}

$\mathrm{Ho}_{1:-}$ - There will be no significant difference between the mean score of 11 years old urban and rural area school students on English Verbal ability test.

$\mathrm{Ho}_{2:-}$ - There will be no significant difference between the mean score of 11 years old boy and girl school students on English Verbal ability test.

$\mathrm{Ho}_{3:-}$ - There will be no significant difference between the mean score of 11 years old urban area boy and girl school students on English Verbal ability test.

$\mathrm{Ho}_{4}$ :- There will be no significant difference between the mean score of 11 years old rural area boy and girl school students on English Verbal ability test.

$\mathrm{Ho}_{5}$ :- There will be no significant difference between the mean score of 11 years old urban and rural area boy school students on English Verbal ability test.

Ho$_{6}$ :- There will be no significant difference between the mean score of 11 years old urban and rural area girl school students on English Verbal ability test.

$\mathrm{Ho}_{7:-}$ There will be no significant difference between the mean score of 12 years old urban and rural area school students on English Verbal ability test.

Ho $_{8}$ - There will be no significant difference between the mean score of 12 years old boy and girl school students on English Verbal ability test.

$\mathrm{Hog}_{9}$ - There will be no significant difference between the mean score of 12 years old urban area boy and girl school students on English Verbal ability test.

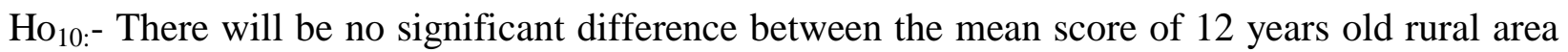
boy and girl school students on English Verbal ability test.

$\mathrm{Ho}_{11:-}$ - There will be no significant difference between the mean score of 12 years old urban and rural area boy school students on English Verbal ability test.

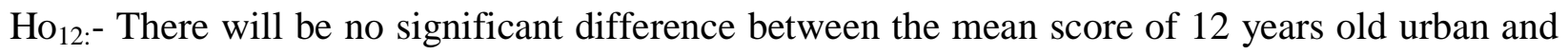
rural area girl school students on English Verbal ability test.

$\mathrm{Ho}_{13:-}$ - There will be no significant difference between the mean score of 13 years old urban and rural area school students on English Verbal ability test.

$\mathrm{Ho}_{14:-}$ There will be no significant difference between the mean score of 13 years old boy and girl school students on English Verbal ability test.

$\mathrm{Ho}_{15:-}$ - There will be no significant difference between the mean score of 13 years old urban area boy and girl school students on English Verbal ability test.

$\mathrm{Ho}_{16:-}$ - There will be no significant difference between the mean score of 13 years old rural area boy and girl school students on English Verbal ability test.

$\mathrm{Ho}_{17:-}$ There will be no significant difference between the mean score of 13 years old urban and rural area boy school students on English Verbal ability test. 


\section{A Study of English Verbal Ability of School Students of Gujarat State with Respect To Gender, Age and Area}

$\mathrm{Ho}_{18:-}$ There will be no significant difference between the mean score of 13 years old urban and rural area girl school students on English Verbal ability test.

\section{Operational Definition}

English Verbal Ability:

The scores obtained by school students on the self constructed English Verbal Ability test were considered as the English Verbal ability of the school students.

\section{Variables:}

Dependent Variables: English Verbal Ability Test Score

Independent variables: Area, sex and age group were taken as independent variables

Abbreviations: EVAT: English Verbal Ability Test

\section{Delimitation}

The study was delimited to students of Gujarat state aged between 11 to 13 years old only.

\section{Design Of The Study:}

Survey method of the research was used in the present study.

\section{Population}

The students of age group from 11 to 13 years old school students studying in geographical area of Gujarat state with medium of instructions English only formed the population for the present study.

\section{Sample}

In the present research all the Gujarat state was divided in the five parts. The Stratified Random Cluster sampling was used for the sample selection. From the selected school classes were selected randomly and all present students of selected class were included in samples for practical convenience. Finally 2204 samples were collected for the data analysis.

\section{Tool}

A self constructed English Verbal Ability test was used to study the English verbal ability test in the Gujarat state. After construction of the first draft, it was reviewed by the experts and finalized after piloting on 250 students. Final test contained 20 items on the English Verbal ability.

\section{Data Collection}

Data collection was done with the self constructed tool from 2204 students. The whole Gujarat state was divided in the five zones for the purpose for the data collection. 

Area

\section{DATA ANALYSIS AND INTERPRETATION:}

Objective I: To study the comparative effect of Gender and Area and Age on the English Verbal Ability of school students.

Under this objective different hypothesis were formulated and were tested using the significance of difference between mean scores using t-ratio. Result of analysis is listed in table 1.1.

Table 1.1: Mean, Sd And T Value Of 11, 12 And 13 Years Old Urban And Rural Area School Students On English Verbal Ability Test

\begin{tabular}{|c|c|c|c|c|c|c|c|c|c|}
\hline Sl No & HO & Area/gender & Age & Number & Mean & SD & SED & $\begin{array}{l}\text { t } \\
\text { Value }\end{array}$ & Remarks \\
\hline \multirow{2}{*}{1} & \multirow{2}{*}{ H01 } & Urban & 11 & 199 & 5.84 & 2.88 & \multirow{2}{*}{0.331} & \multirow{2}{*}{0.99} & \multirow{2}{*}{ Accepted } \\
\hline & & Rural & 11 & 86 & 5.81 & 2.42 & & & \\
\hline \multirow{2}{*}{2} & \multirow{2}{*}{$\mathrm{H} 02$} & Boys & 11 & 174 & 5.7 & 2.7 & \multirow{2}{*}{0.328} & \multirow{2}{*}{2.43} & \multirow{2}{*}{$\begin{array}{l}\text { Rejected at } 0.05 \\
\text { level }\end{array}$} \\
\hline & & Girls & 11 & 111 & 6.5 & 2.7 & & & \\
\hline \multirow{2}{*}{3} & \multirow{2}{*}{ H03 } & U Boys & 11 & 114 & 5.72 & 2.83 & \multirow{2}{*}{0.416} & \multirow{2}{*}{0.93} & \multirow{2}{*}{ Accepted } \\
\hline & & U Girls & 11 & 85 & 6.11 & 2.96 & & & \\
\hline \multirow{2}{*}{4} & \multirow{2}{*}{ H04 } & R Boys & 11 & 60 & 5.65 & 2.68 & \multirow{2}{*}{0.476} & \multirow{2}{*}{1.13} & \multirow{2}{*}{ Accepted } \\
\hline & & R Girls & 11 & 26 & 6.19 & 1.67 & & & \\
\hline \multirow{2}{*}{5} & \multirow{2}{*}{ H05 } & U Boys & 11 & 114 & 5.72 & 2.83 & \multirow{2}{*}{0.436} & \multirow{2}{*}{0.16} & \multirow{2}{*}{ Accepted } \\
\hline & & R Boys & 11 & 60 & 5.65 & 2.68 & & & \\
\hline \multirow{2}{*}{6} & \multirow{2}{*}{ H06 } & U Girls & 11 & 85 & 6.11 & 2.96 & \multirow{2}{*}{0.459} & \multirow{2}{*}{0.17} & \multirow{2}{*}{ Accepted } \\
\hline & & R Girls & 11 & 26 & 6.19 & 1.67 & & & \\
\hline 7 & $\mathrm{H} 07$ & Urban & 12 & 291 & 7.32 & 3.28 & 0330 & 351 & Rejected at 0.01 \\
\hline 1 & HO/ & Rural & 12 & 122 & 6.16 & 2.96 & 0.330 & 3.51 & level \\
\hline 8 & $\mathrm{HOR}$ & Boys & 12 & 240 & 6.87 & 3 & 0330 & 078 & Accented \\
\hline 0 & HणO & Girls & 12 & 173 & 7.13 & 3.52 & 0.350 & 0.10 & Ассертеа \\
\hline 0 & HOO & U Boys & 12 & 162 & 7.36 & 3.2 & & & \\
\hline 9 & HUY & U Girls & 12 & 129 & 7.27 & 3.37 & 0.389 & 0.23 & Accepted \\
\hline & & R Boys & 12 & 78 & 5.84 & 2.19 & & & \\
\hline 10 & H010 & R Girls & 12 & 44 & 6.72 & 3.11 & 0.530 & 1.65 & Accepted \\
\hline 11 & H011 & U Boys & 12 & 162 & 7.36 & 3.21 & 0254 & ר 20 & Rejected at 0.01 \\
\hline 11 & HU11 & R Boys & 12 & 78 & 5.84 & 2.19 & 0.354 & 4.29 & level \\
\hline & & U Girls & 12 & 129 & 7.27 & 3.37 & 0555 & & \\
\hline 12 & H012 & R Girls & 12 & 44 & 6.72 & 3.11 & 0.555 & 0.99 & Accepted \\
\hline 12 & HO12 & Urban & 13 & 308 & 7.65 & 3.12 & & & \\
\hline 13 & HOI3 & Rural & 13 & 97 & 7.36 & 3.62 & 0.408 & 0.7 & Accepted \\
\hline 14 & HO14 & Boys & 13 & 233 & 7.31 & 2.98 & 0307 & 208 & Rejected at 0.05 \\
\hline 14 & HU14 & Girls & 13 & 172 & 7.95 & 3.11 & $0.30 /$ & 2.08 & level \\
\hline
\end{tabular}

(c) The International Journal of Indian Psychology, ISSN 2348-5396 (e)| ISSN: 2349-3429 (p) | 133 
A Study of English Verbal Ability of School Students of Gujarat State with Respect To Gender, Age and Area

\begin{tabular}{|l|l|l|l|l|l|l|l|l|l|}
\hline \multirow{2}{*}{15} & \multirow{2}{*}{$\begin{array}{l}\text { H01 } \\
5\end{array}$} & U Boys & 13 & 176 & 7.4 & 3.1 & \multirow{2}{*}{0.368} & 1.63 & \multirow{2}{*}{ Accepted } \\
\cline { 2 - 10 } & U Girls & 13 & 132 & 8.0 & 3.26 & & & \\
\hline \multirow{2}{*}{16} & $\begin{array}{l}\text { H01 } \\
6\end{array}$ & R Boys & 13 & 57 & 7.05 & 3.62 & \multirow{2}{*}{0.748} & \multirow{2}{*}{1.0} & \multirow{2}{*}{ Accepted } \\
\cline { 2 - 10 } & R Girls & 13 & 40 & 7.8 & 3.63 & & & \\
\hline \multirow{2}{*}{17} & $\begin{array}{l}\text { H01 } \\
7\end{array}$ & U Boys & 13 & 176 & 7.4 & 3.1 & \multirow{2}{*}{0.533} & 0.65 & \multirow{2}{*}{ Accepted } \\
\cline { 2 - 10 } & R Boys & 13 & 57 & 7.05 & 3.62 & & & \\
\hline \multirow{2}{*}{18} & \multirow{2}{*}{$\begin{array}{l}\text { H01 } \\
8\end{array}$} & U Girls & 13 & 132 & 8.0 & 3.26 & \multirow{2}{*}{0.640} & 0.31 & Accepted \\
\cline { 2 - 9 } & R Girls & 13 & 40 & 7.8 & 3.63 & & & \\
\hline
\end{tabular}

1. H01: It is found from the table 1.1 that there is no significant difference between the English verbal Ability of 11 years old urban and rural students. Thus H01 was accepted.

2. H02: It is found from the table 1.1 that there was significant difference between the English verbal Ability of 11 years old boy and girl students at 0.05 level. Thus $\mathbf{H 0 2}$ was rejected at 0.05 level.

3. H03: It is found from the table 1.1 that there is no significant difference between the English verbal Ability of 11 years old urban boy and urban girl students. Thus H03 was accepted.

4. H04: It is found from the table 1.1 that there is no significant difference between the English verbal Ability of 11 years old rural boy and girl students. Thus H04 was accepted.

5. H05: It is found from the table 1.1 that there is no significant difference between the English verbal Ability of 11 years old urban and rural boy students. Thus H05 was accepted.

6. H06: It is found from the table 1.1 that there is no significant difference between the English verbal Ability of 11 years old urban and rural girl students. Thus H06 was accepted.

7. H07: It is found from the table 1.1 that there was significant difference between the English verbal Ability of 12 years old urban and rural students at 0.01 level. Thus $\mathbf{H 0 7}$ was rejected at 0.01 level.

8. H08: It is found from the table 1.1 that there is no significant difference between the English verbal Ability of 12 years old boy and girl students. Thus $\mathbf{H 0 8}$ was accepted.

9. H09: It is found from the table 1.1 that there is no significant difference between the English verbal Ability of 12 years old urban boy and girl students. Thus H09 was accepted.

10. H010: It is found from the table 1.1 that there is no significant difference between the English verbal Ability of 12 years old Rural boy and girl students. Thus H010 was accepted.

11. H011: It is found from the table 1.1 that there was significant difference between the English verbal Ability of 12 years old urban and rural boy students at 0.01 level. Thus H011 was rejected at 0.01 level. 
A Study of English Verbal Ability of School Students of Gujarat State with Respect To Gender, Age and Area

12. H012: It is found from the table 1.1 that there is no significant difference between the English verbal Ability of 12 years old urban and rural girl students. Thus $\mathbf{H 0 1 2}$ was accepted.

13. H013: It is found from the table 1.1 that there is no significant difference between the English verbal Ability of 13 years old urban and rural students. Thus H013 was accepted.

14. H014: It is found from the table 1.1 that there was significant difference between the English verbal Ability of 13 years old boy and girl students at 0.05 level. Thus $\mathbf{H 0 1 4}$ was rejected at 0.05 level.

15. H015: It is found from the table 1.1 that there is no significant difference between the English verbal Ability of 13 years old urban boy and girl students. Thus H015 was accepted.

16. H016: It is found from the table 1.1 that there is no significant difference between the English verbal Ability of 13 years old rural boy and girl students. Thus $\mathbf{H 0 1 6}$ was accepted.

17. H017: It is found from the table 1.1 that there is no significant difference between the English verbal Ability of 13 years old urban and rural boy students. Thus $\mathbf{H 0 1 7}$ was accepted.

18. H018: It is found from the table 1.1 that there is no significant difference between the English verbal Ability of 13 years old urban and rural girl students. Thus $\mathbf{H 0 1 8}$ was accepted.

\section{MAJOR FINDINGS}

1. 11 years old Girls students have the higher English Verbal Ability than 11 years old boy students.

2. 12 years old urban area students have the higher English Verbal Ability than rural area students.

3. 12 years old urban area boy students have the higher English Verbal Ability than rural area boy students.

4. 13 years old Girl students have the higher English Verbal Ability than 13 years old boy students.

\section{EDUCATIONAL IMPLICATION}

In English Verbal ability test, mean scores of urban area school students were found higher than rural area school students, means that English Verbal ability of urban area school students were higher in comparison to rural area. This result shows that teachers have to organize tutorial and guidance programme during academic sessions, which can enhance the abilities of rural area students and helps them to increase their English Verbal ability. There is a need to put more emphasis on the learning of English in the rural area students, so that the gap between urban and rural can be bridged. 


\section{A Study of English Verbal Ability of School Students of Gujarat State with Respect To Gender, Age and Area}

In English Verbal ability test, mean scores of girls school students were found to be higher than to boys students. This result shows that teacher have to make boys aware of need and role of language aptitude in educational and occupational fields. Teachers should also help the girls who are excellent in the verbal ability to excel in the field of literature and other allied fields. Teachers should also take efforts on improving the verbal ability of boys and have remedial teaching. On other hand for girls students, teachers should make efforts to further their interest in English Verbal communication and writing to have them better command over English language.

\section{Acknowledgments}

The author appreciates all those who participated in the study and helped to facilitate the research process.

\section{Conflict of Interests}

The author declared no conflict of interests.

\section{REFERENCES}

Aggarwl, Y.P. (2009). Statistical Methods (3rd Ed.). New Delhi: Sterling Publisher Private Limited.

Anastasi, A. (1959). Psychological Testing. New York: The Mac Millen Company.

Best J. and Kahn J. (1986). Research in Education. New Delhi: Prentice Hall of India Private Limited.

Bingham, W. (1970). Aptitude \& Aptitude testing. New York: Harper \& Brother Publisher.

Biswas, A. and Aggarwal, J. (1971). Encyclopedic Dictionary and Dictionary of Education. New Delhi: The Academic Publisher (India).

Brown, F.G. (1970). Principles of Educational and Psychological Testing. New York: Host, Rinehart and Winstone.

Buch, M.B. (Ed.). (1997). Fifth Survey of Research in Education. (1988-1992). New Delhi: National Council of Educational Research and Training.

Cattell, R. (2008). Psychological Testing. New Delhi: Shrishti Book Distributors.

Dash, B. and Dash, N. (2003). Educational Measurement Statistics \& Guidance Services. Delhi: Dominant Publishers and Distributors.

Eral, J.E. (2001). Oxford Dictionary \& Thesaurus. New York: Oxford university press.

Garrett, H.E. (2006). Statistics in Psychology and Education. Delhi: Surjeet Publications.

How to cite this article: Gupta S, Yadav S (2017), A Study of English Verbal Ability of School Students of Gujarat State with Respect To Gender, Age and Area, International Journal of Indian Psychology, Volume 4, Issue 2, No. 85, ISSN:2348-5396 (e), ISSN:2349-3429 (p), DIP:18.01.016/20170402, ISBN: 978-1-365-68608-5 